\title{
Analisis Transmisi Harga Jagung sebagai Bahan Pakan Ternak Ayam Ras di Sumatera Barat
}

\section{Analyze of Price Transmission Maize as Feed of Poultry in West Sumatera}

\author{
E. Rahmi dan B. Arif \\ Fakultas Peternakan Universitas Andalas, \\ Kampus Unand Limau Manis Padang, 25163 \\ Email : elfirahmi_82@yahoo.co.id
}

(Diterima: 12 Desember 2011; Disetujui: 16 Februari 2012)

\begin{abstract}
The reseacrh was conducted in West Pasaman West Sumatera. There was a phenomenon in the research area that poultry farmers had difficulty to get maize for layer feed and the tendency of price increase of maize after the operation of feed industry. The purpose of the reseacrh were to analyze the elasticity of price transmission between producers and consumers pricing. Method of the research was a quantitative description and statistic analyze to measure elasticity of price transmission between producers and consumers pricing. Data used in the research was secondary data. The result of research revealed that elasticity of price transmission was small $(\eta=0,26)$, indicated that the price change at farmer level was lower than consumers level therefore the market of maize in West Sumatera was not efficient.
\end{abstract}

Keyword: price transmission, producers pricing, consumers pricing.

\section{PENDAHULUAN}

Permintaan meningkat, penawaran meningkat, seharusnya kekuatan penawaran dan permintaan bekerja dengan baik sesuai mekanisme pasar sehingga terbentuk harga keseimbangan, namun dalam kasus pasar jagung di Sumatera Barat menunjukkan penawaran jagung meningkat setiap tahun, akan tetapi permintaan tidak terpenuhi dan harga yang terbentuk sangat tinggi. Tingginya harga yang diterima konsumen peternak ayam ras merupakan komponen dari biaya produksi dan biaya yang terbentuk melalui sistem pemasaran jagung.

Harga akhir yang terbentuk seharusnya dapat memuaskan semua pelaku pasar jagung, baik petani jagung sebagai produsen maupun peternak ayam ras petelur sebagai konsumen sebagai akibat adanya nilai margin yang timbul dalam proses pemasaran akibat fungsi pemasaran yang terjadi. Peternak ayam ras sebagai konsumen jagung sangat sulit mendapatkan jagung dan harganya naik dari Rp.2.200-2.400/kg menjadi Rp.3.100-3.500/ kg (harga pada awal tahun 2010). Peternak tidak mampu menutupi biaya produksi, peternak yang berskala usaha kecil terpaksa menutup usaha. Terutama pada ayam petelur, kenaikan harga jagung tidak diikuti oleh kenaikan harga telur, harga telur justru turun dari harga Rp.800-1.000/butir menjadi Rp.600/butir (harga awal tahun 2010), sehingga peternak tidak mampu menutupi biaya pakan, sementara komponen biaya pakan dalam usaha peternakan adalah komponen yang paling besar dari total biaya produksi yaitu mencapai 60-70 persen (Asosiasi Peternak Ayam Sumatera Barat, 2010 dan Rasyaf, 2003).

Permasalahan mahalnya harga jagung tersebut menjadi beberapa tajuk utama di pemberitaan harian lokal Sumatera Barat, diantaranya adalah bertajuk : Peternak Terancam Bangkrut, Harga Jagung Termahal Harga Telur Turun (Padang Ekspres, Senin/22 Maret 2010), Peternak Ayam Dirundung Malang Dulu Stress Flu Burung, Kini Panik Harga Jagung (Padang Ekspres, Senin/22 Maret 2010), Peternak Terlilit Gurita Bisnis Bangun Pabrik Pakan Secara Terpadu (Padang Ekspres, Jum'at/26 Maret 2010), Peternak 
Ayam Terancam Gulung Tikar Harga Pakan Melonjak Naik (Padang Ekspres, Jum'at/9 Tabel 1. Perkembangan Harga Jagung dan Telur di Provinsi Sumatera Barat 2005-2009

\begin{tabular}{ccc}
\hline Tahun & Harga Jagung $(\mathrm{Rp} / \mathrm{Kg})$ & Harga Telur $(\mathrm{Rp} /$ Butir $)$ \\
\hline 2005 & 1.900 & 650 \\
2006 & 2.100 & 700 \\
2007 & 2.200 & 880 \\
2008 & 2.800 & 1050 \\
2009 & 2.900 & 780 \\
\hline \% Peningkatan & 9,7 & 2,3 \\
\hline
\end{tabular}

April 2010), Harga Jagung Sumbar Termahal (Padang Ekspres. Senin/10 Mei 2010). Perkembangan harga jagung dan harga telur di Sumatera Barat dapat dilihat pada Tabel 1.

Tingginya harga yang diterima konsumen peternak merupakan komponen dari biaya produksi dan biaya yang terbentuk melalui sistem pemasaran jagung. Pedagang jagung memiliki hak dalam menentukan keputusan sistem pemasaran yang digunakan dan biaya pemasaran. Lingkungan ekonomi yang bersaing secara sempurna, harga harus benar-benar sama dengan semua biaya. Permintaan konsumen tercermin dalam sistem pemasaran melalui mekanisme harga yang mengakibatkan terjadinya keuntungan atau kerugian. Harga akhir yang terbentuk seharusnya dapat memuaskan semua pelaku pasar, baik petani jagung sebagai produsen maupun peternak ayam ras petelur sebagai konsumen sebagai akibat adanya nilai margin yang timbul dalam proses pemasaran akibat fungsi pemasaran yang terjadi.

Tingkat efisiensi pemasaran dapat dilihat dari distribusi marjin antar mata rantai pemasaran. Namun demikian efisiensi pemasaran bersifat relatif tergantung dari aspek mana atau pelaku mana melihatnya. Rusastra (2002) menyatakan, bagi petani, pemasaran dikatakan efisien jika tingkat harga yang diterimanya (farmer share) tinggi dan semakin membaik. Akan tetapi secara umum efisiensi pemasaran terjadi apabila marjin terdistribusi merata, berarti transmisi harga dari konsumen ke produsen dan sebaliknya dari produsen ke konsumen dapat berjalan dengan baik. Berlaku sebaliknya apabila terjadi penum- pukan marjin berarti terdapat pelaku pasar yang mengendalikan pasar dan menghambat transmisi harga.

\section{METODE}

Aspek yang menjadi obyek penelitian adalah harga jagung. Data sekunder diperoleh dari instansi terkait diantaranya Badan Pusat Statistik Provinsi Sumatera Barat maupun Badan Pusat Statistik Kabupaten Pasaman Barat, Dinas Pertanian Tanaman Pangan dan Hortikultura Provinsi Sumatera Barat dan Kabupaten Pasaman Barat, Dinas Peternakan Provinsi Sumatera Barat, dan Balai Penyuluhan Pertanian Ketahanan Pangan Kabupaten Pasaman Barat serta Dinas Perindustrian Perdagangan dan Koperasi Provinsi Sumatera Barat.

Analisis dikaji dari fenomena tingginya harga jagung di Sumatera Barat dilakukan dengan melihat integrasi pasar yang terjadi antara pasar di tingkat produsen jagung di daerah sentra produksi dan pasar di tingkat konsumen jagung yaitu peternak ayam ras di daerah sentra produksi, yang dijadikan pasar acuan penentuan harga. Pada pasar yang terintegrasi perubahan harga pada tingkat pasar konsumen akan mempengaruhi harga pada tingkat pasar produsen. Untuk melihat integrasi pasar dilihat dari nilai elastisitas transmisi harga menggunakan regresi linier sederhana.

Hubungan elastisitas harga di tingkat petani dan konsumen, dapat dilihat dari elastisitas transmisi harganya, yaitu rasio perubahan nisbi dari harga eceran dengan 
perubahan nisbi harga di tingkat petani produsen (Azzaino, 1982). Dengan formulasi sebagai berikut :

$$
\eta=\frac{\delta \operatorname{Pr}}{\delta \operatorname{Pf}}: \frac{\operatorname{Pf}}{\operatorname{Pr}}
$$

Dimana:

$$
\begin{aligned}
\eta & =\text { elastisitas transmisi harga } \\
\delta \operatorname{Pr} & =\text { perubahan harga di tingkat kon- } \\
& \text { sumen, } \\
\delta \mathrm{Pf} & =\text { perubahan harga di tingkat produsen } \\
\operatorname{Pr} & =\text { harga di tingkat konsumen, } \\
\operatorname{Pf} & =\text { harga di tingkat petani produsen }
\end{aligned}
$$

Parameter tersebut dapat diduga dengan menggunakan metode regresi linier sederhana sebagai berikut :

Sehingga,

$$
\mathrm{Pf}=\mathrm{a}+\mathrm{b} \operatorname{Pr}
$$

$$
\begin{aligned}
& \eta=\frac{\delta P r}{\delta P f}: \frac{P f}{P r} \\
& \eta=\frac{1}{1-b} \frac{P f}{P r}
\end{aligned}
$$

Jika,

$\eta=1$, maka kepekaan perubahan nisbi harga di tingkat petani sama dengan kepekaan perubahan harga di tingkat konsumen

$\eta>1$, maka kepekaan perubahan nisbi harga di tingkat petani lebih besar dari kepekaan perubahan harga di tingkat konsumen

$\eta<1$, maka kepekaan perubahan nisbi harga di tingkat petani lebih kecil dari kepekaan perubahan harga di tingkat konsumen

Elastisitas transmisi harga artinya perubahan harga $1 \%$ di tingkat konsumen akan mengakibatkan perubahan di tingkat produsen. Uji hipotesis adalah dengan menggunakan uji $\mathrm{t}$, adapun kaidah kepu-

Tabel 2. Hasil Regresi Antara Perubahan Harga di Tingkat Konsumen dengan Perubahan Harga di Tingkat Produsen Jagung

\begin{tabular}{lcccrr}
\hline & B & SE B & Beta & T & \multicolumn{1}{c}{ Sig. T } \\
\hline Pf & 0,260047281 & 0,176928157 & 0,197898325 & 1,469790255 & 0,1475302 \\
(Constant) & 30,54373522 & 12,28113616 & & 2,487044751 & 0,016063873 \\
\hline
\end{tabular}

tusannya adalah jika $\eta$ bernilai $\operatorname{sig}\langle 0,05>$ sig.

\section{HASIL DAN PEMBAHASAN}

Pedagang jagung memiliki hak dalam menentukan keputusan sistem pemasaran yang digunakan dan biaya pemasaran. Lingkungan ekonomi yang bersaing secara sempurna, harga harus benar-benar sama dengan semua biaya. Permintaan konsumen tercermin dalam sistem pemasaran melalui mekanisme harga yang mengakibatkan terjadinya keuntungan atau kerugian.

Dalam teori pemasaran, Downey dan Erickson (1987) mengatakan bahwa efisiensi penetapan harga berkaitan dengan keefektifan harga dalam mencerminkan biaya keluaran yang bergerak melalui sistem pemasaran. Harga yang dibayar konsumen dari sistem pemasaran harus mencerminkan secara tepat biaya pemasaran dan biaya produksi. Pasar yang didominasi oleh beberapa pedagang yang memasang harga tinggi, maka dari segi penetapan harga hal tersebut tidak efisien. Hal yang mengakibatkan ketidakefisienan penetapan harga, diantaranya konsumen yang kurang mendapat cukup informasi, atau ada pihak yang mendominasi pasar, sehingga harga tidak mencerminkan biaya yang selayaknya.

Untuk melakukan analisis transmisi harga antara harga jagung di tingkat konsumen dengan harga di tingkat produsen, pada penelitian ini digunakan data sekunder, yaitu harga jagung di tingkat produsen dan tingkat konsumen di Propinsi Sumatera Barat per minggu selama satu tahun (Agustus 2009 Agustus 2010) dari Data Dinas Perindustrian Perdagangan dan Koperasi Propinsi Sumatera Barat ). Hasil analisis transmisi harga dengan regresi linier sederhana disajikan pada Tabel 2. 
Keterangan: tanda* : signifikan pada $(\alpha=5 \%, 1 \%)$. T Tabel 0,05 $=2,005$. $\mathrm{T}$ Tabel $0,01=2,670$

Persamaannya dapat ditulis dapat ditulis sebagai berikut :

$$
\begin{gathered}
\Delta \mathrm{Pf}=\alpha+\Delta \mathrm{Pr} \\
\Delta \mathrm{Pf}=30,544+0,260 \operatorname{Pr}
\end{gathered}
$$

Dari persamaan di atas, maka elastisitas transmisi harga adalah sebesar nilai koefisien regresi yaitu $\eta=0,26<1$ (in elastis). Nilai $\eta=$ 0,26 mengindikasikan bahwa kepekaan perubahan harga di tingkat petani jagung lebih kecil dari kepekaan perubahan harga di tingkat konsumen sehingga pasar kurang efisien. Hal ini disebabkan oleh harga yang tinggi pada konsumen pabrik pakan, diikuti oleh perubahan harga yang diterima oleh peternak ayam ras sebagai konsumen lain. Petani relatif sedikit mengalami perubahan harga, karena perubahan harga hanya berakibat pada besarnya profit pedagang pengumpul.

Ariningsih (2008), nilai elastisitas transmisi komoditas pertanian lebih kecil daripada satu, artinya volume dan harga input konstan maka perubahan nisbi harga ditingkat pengecer tidak akan melebihi perubahan nisbi harga ditingkat petani. Nilai koefisien regresi $\ln P r$ menggambarkan besarnya elastisitas transmisi harga antara harga ditingkat petani dengan harga ditingkat konsumen. Jika $\eta=1$, berarti perbedaan harga tingkat produsen dan konsumen hanya dibedakan oleh margin pemasaran yang tetap. Jika $\eta>1$, maka kepekaan perubahan nisbi harga di tingkat petani lebih besar dari kepekaan perubahan harga di tingkat konsumen. Jika $\eta<1$, maka kepekaan perubahan nisbi harga di tingkat petani lebih kecil dari kepekaan perubahan harga di tingkat konsumen. Produk-produk pertanian biasanya memiliki nilai elastisitas transmisi harga kecil dari satu, seperti beberapa hasil : (Sari, 2000), elastisitas transmisi harga jagung di Kabupaten Lampung Tengah adalah 0,85 ; Sutawi (2002), nilai elastisitas transmisi harga jagung di Kabupaten Malang sebesar 0,628 ; Nur (2008), nilai elastisitas transmisi harga sapi pedet perah sebesar 0,853 ; Suharyanto, (2005) menunjukkan nilai elastisitas transmisi harga anggur di Bali sebesar 0.199 ; Lakebo
(2003), hasil analisis elastisitas transmisi harga kakao, didapatkan angka $<1$.

Data yang digunakan untuk menganalisis transmisi harga pada penelitian ini adalah data harga produsen dan konsumen jagung di tingkat propinsi. Harga di tingkat propinsi merupakan data harga yang diambil dari daerah sentra produksi oleh pemerintah propinsi. Data yang digunakan adalah besarnya nilai perubahan harga di tingkat produsen dan perubahan harga di tingkat konsumen dari minggu ke minggu selama satu tahun. Elastisitas transmisi harga pada perubahan harga tersebut sama dengan koefisien perubahan harga pada regresi linier sederhana (Tekguc, 2010). Dalam Rencana Strategis Program Pembangunan Pengolahan dan Pemasaran Hasil Pertanian Tahun 20052009 (Dirjen Pengolahan dan Pemasaran Hasil Pertanian, Departemen Pertanian), juga telah dijelaskan bahwa dinamika permasalahan dan tantangan dalam lingkungan strategis pembangunan pertanian domestik adalah struktur usaha yang bersifat dispersal atau tersekat-sekat pada masing-masing pelaku usaha. Tidak ada kaitan institusional antara masing-masing pelaku usaha walaupun sebenarnya saling terkait secara fungsional. Keterkaitan antar pelaku usaha, hanya terbentuk melalui harga. Pada kondisi dispersal, yang kuat akan dominan dalam pembentukan harga. Struktur usaha demikian tidak kondusif bagi pembangunan pertanian/ agribisnis yang berkelanjutan, akibat tidak adanya kaitan fungsional yang serasi dan harmonis diantara pelaku agribisnis sehingga dinamika pasar tidak selalu dapat direspon secara efisien. Konsekuensinya adalah transmisi harga dan informasi pasar yang bersifat asimetris dan terbentuknya marjin ganda sehingga pemasaran hasil pertanian tidak efisien.

Benny (2001) menjelaskan dinamika harga jagung di Indonesia, upaya 
menstabilkan harga jagung di dalam negeri mulai tahun 1977/78, pemerintah memberi mandat kepada Bulog melakukan pengadaan jagung yang bersumber dari petani dan impor. Sejalan dengan perkembangannya, kebijakan harga dasar jagung dinilai tidak efektif dan kemudian dihentikan pada tahun 1990, karena harga pasar di tingkat petani senantiasa berada diatas harga dasar. Tataniaga jagung dibebaskan kepada pedagang swasta sehingga harga jagung ditentukan oleh mekanisme pasar. Zain (2007), menambahkan bahwa memasuki tahun 1998 harga jagung di pasar dunia meningkat tajam mencapai tingkat harga tertinggi yaitu Rp 2020 per kg. Selanjutnya, dinamika harga pada bulan Agustus 1998 di pasar dunia mencapai harga terendah yaitu $\mathrm{Rp}$ 770 per $\mathrm{kg}$, dan cenderung meningkat hingga akhir tahun 2000. Meningkatnya harga tersebut erat kaitannya dengan fluktuasi nilai tukar rupiah. Kuatnya pengaruh harga jagung dunia terhadap harga jagung domestik tercermin dari besaran nilai transmisi harganya yang mendekati satu. Namun demikian, cepat dan kuatnya transmisi harga dunia tersebut membawa pengaruh perubahan harga di pasar domestik yang tidak proporsional, perubahan harga relatif di pasar dunia ( $\mathrm{e}=0,77)$ diikuti perubahan harga relatif yang lebih besar di pasar domestik (e =0,81). Kecenderungan yang sama di pasar domestik, untuk harga jagung di tingkat konsumen ditransmisikan langsung ke tingkat produsen. Eratnya korelasi harga pasar tersebut terlihat dari nilai transmisi harga yang cukup tinggi $(0,89)$. Tingkat transmisi harga dunia ke harga pedagang besar serta transmisi harga pedagang besar ke harga di tingkat produsen dipengaruhi oleh sistem pemasaran dari komoditas tersebut. Dengan pengertian lain, semakin efisien suatu sistem pemasaran, semakin tinggi elastisitas transmisi harga dan semakin kecil marjin pemasaran.

\section{KESIMPULAN}

Kepekaan perubahan harga di tingkat petani jagung lebih kecil dari kepekaan perubahan harga di tingkat konsumen sehingga pasar kurang efisien. Transmisi harga dari konsumen ke produsen dan sebaliknya dari produsen ke konsumen kurang berjalan dengan baik, karena penumpukan marjin pada pedagang pengumpul sebagai pelaku pasar yang mengendalikan pasar dan menghambat transmisi harga. Petani relatif sedikit mengalami perubahan harga, karena perubahan harga hanya berakibat pada besarnya profit pedagang pengumpul, sehingga petani sendiri sebagai produsen jagung dan peternak ayam ras sebagai konsumen jagung untuk bahan pakan ternaknya tidak diuntungkan dengan kondisi pasar jagung yang ada.

\section{DAFTAR PUSTAKA}

Ariningsih, A.,Hendiarto, Jamal, G. 2008. Analisis Kebijakan Penentuan Harga Pembelian Gabah. Pengembangan Inovasi Pertanian Vol.1 no.(1), 2008:7481. Pusat Analisis Sosial Ekonomi \& Kebijakan Pertanian, Bogor. Departemen Pertanian.

Azzaino, Z. 1982. Pengantar Tataniaga Pertanian. Bogor : Ilmu Sosial Ekonomi Pertanian, IPB.

Benny, R. 2001. Dinamika Harga dan Perdagangan Komoditas Jagung. Pusat Penelitian \& Pengembangan Sosial Ekonomi Pertanian Bogor. Badan Litbang-Departemen Pertanian. Analisis Kebijakan Pertanian ISSN : 1693-2021

Downey, D.W \& Erickson, S.P. 1987. Manajemen Agribisnis - Edisi Kedua. Jakarta : Penerbit Erlangga

Han, S \& Durham, C.A. 2010. Spatial Price Analysis Incorporating Rate of Trade: Methods and Application to United States-China Soybean Trade. Journal of Agricultural and Applied Economics, 42,2 (May 2010) : 367_382_2010 Southern Agricultural Economics Association.

Lakebo, R.J. 2003. Analisis Efisiensi Pemasaran Komoditas Kakao di 
Kabupaten Kolaka. Tesis. Pascasarjana Universitas Gadjah Mada Yogyakarta

Nur, K.M. 2008. Efisiensi Pemasaran Pedet Jantan Sapi Perah. Tesis. Program Pascasarjana Universitas Muhammadiyah Malang.

Rusastra, I.W., Benny, R.,Sumedi, Sudaryanto, T. 2002. Struktur Pasar dan Pemasaran Gabah-Beras dan Komoditas Kompetitor Utama. Pusat Penelitian \& Pengembangan Sosial Ekonomi Pertanian Bogor. Badan Litbang-Departemen Pertanian. Analisis Kebijakan Pertanian ISSN : 1693-2021

Sari, A. 2000. Pemasaran Jagung Sebagai Bahan Baku Industri Pakan Ternak (Studi Kasus Daerah Produksi Jagung di Kab. Lampung Tengah). Tesis. Universitas Padjadjaran.

Suharyanto, Parwati, I.A.P., Rinaldi, J. 2005. Analisis Pemasaran dan Tataniaga Anggur di Bali. Balai Pengkajian Teknologi Pertanian Bali
Sumaryanto. 2009. Analisis Volatilitas Harga Eceran Beberapa Komoditas pangan Utama Dengan Model ARCH/GARCH. Jurnal Agro Ekonomi Vol.27 no.2 Oktober 2009 ISSN 0216 - 9053.

Sutawi. 2002. Analisis Pemasaran Jagungdi Kecamatan Singosari Kabupaten Malang.Melalui.http://elib.unikom.ac.id/ gdl.php? mod=browse\&op=read\&id=jipt umm-gdl-res-2002-ir-5318-jagung

Tekguc, H. 2010. Oligopoly And Price Transmission in Turkey's Fluid Milk Market. Paper Prepared For Presentation at The 114th EAAE Seminar 'Structural Change in Agriculture', Berlin, Germany, April 15 - 16, 2010. Department of Economics, University of Massachusetts Amherst, USA. Agecon Journal.

Zain, M.M. 2007. Perspektif Perdagangan Bebas Antar Pulau. Analisis September 2007 Vol.4 no.2:111-123 ISSN 08528144. 